Bulletin of PharmaceuticalSciences
Assiut University

\title{
MACRO- AND MICROMORPHOLOGY OF THE LEAVES, STEMS, SEEDS AND FRUITS OF IPOMOEA ERIOCARPA (R. Br.) GROWING IN EGYPT
}

\author{
A. A. Khalifa, A. A. Mohamed, Z. Z. Ibrheim and A. M. A. Hamoda* \\ Department of Pharmacognosy, Faculty of Pharmacy, Assiut University, Assiut, Egypt

\begin{abstract}
Ipomoea eriocarpa R.Br. belongs to family Convolvulaceae often called morning glories, are summer annual or perennial broadleaf plants. They are slender twining herb. It is occasionally consumed as an edible leafy vegetable or mixed with other food. An oil extract of Ipomoea eriocarpa is used for external application in headache, rheumatism, leprosy, ulcers and fevers. By reviewing the current literature, no botanical studies were done on Ipomoea eriocarpa R.Br., so this study aims to characterization and identification of this plant in both powdered and entire forms.
\end{abstract}

\section{INTRODUCTION}

The family Convolvulaceae is derived from a latin name Convolvere, meaning "To wind". It is commonly known as bindweed or morning glory family. They are a group of 5060 genera and about $1600-1700$ species $^{1 \& 2}$. More than one-third of the species are included in two major genera, Ipomea and Convolvulus. Convolvulaceae species are distributed throughout the world, but primarily in tropical regions. Many tropical species are valuable ornamentals, medicinal, and foodcrops ${ }^{1 \& 3}$. The family exhibiting a rich diversity of morphological characters and a wide range of ecological habitats. It is herbaceous, twining, or woody, climbing or trailing vines, shrubs or trees $^{4 \& 5}$.

The genus Ipomoea has been used for different purposes, such as nutritional, medicinal, ritual and agricultural ${ }^{6}$. The genus Ipomoea occurs in the tropics of the world although some species also reach temperate zones $^{7}$. Ipomoea eriocarpa is widespread in tropical Africa including Madagascar, extending to South Africa and Egypt, and occurs also in tropical Asia and northern Australia ${ }^{8}$. The leaves of Ipomoea eriocarpa are eaten in Africa and India as a cooked vegetable, in soups or mixed with other food. In Uganda a root decoction is drunk by women to relieve menstrual pain. In India, an oil extract of the plant is used externally against headache, rheumatism, leprosy, epilepsy, ulcers and fever. In veterinary medicine, the oil extract is used to cure wounds of cattle ${ }^{9}$.

Ipomoea eriocarpa leaves have antimicrobial activity against $E$. coli and Aspergillus niger ${ }^{10}$. The whole plant of Ipomoea eriocarpa has antioxidant activity by using DPPH radical scavenging, and reducing power assays ${ }^{11}$ and exhibited potent insecticidal activity and good anthelmintic activity $^{10}$.

The preliminary phytochemical analysis of Ipomoea eriocarpa revealed the presence of alkaloids, phenols, saponins, phytosterols, flavanoids and terpenoids ${ }^{12}$.

Concerning macro- and micromorphological study of this plant, nothing could be traced. This encourage us to undergo a macro-and micro-morphological study of the leaves, stems, seeds and fruits.

\section{Habitat}

Ipomoea eriocarpa (R.Br.) is annual morning glories, summer annual or perennial 
broadleaf plants. Mature plants have long stems that climb and twine. Leaves are large, heart shaped, petiolate. Flowers are bisexual tubular to funnel-shaped, up to $1 \mathrm{~cm}$ long, pink with dark centre. Fruits are a globose to ovoid capsule $6 \mathrm{~mm}$ long. Seeds are ovoid, black germinate down to a depth of 4 inches or more, much deeper than most annuals. Ipomoea eriocarpa R.Br. are often cultivated as ornamentals, but under favorable conditions they can become troublesome weeds.

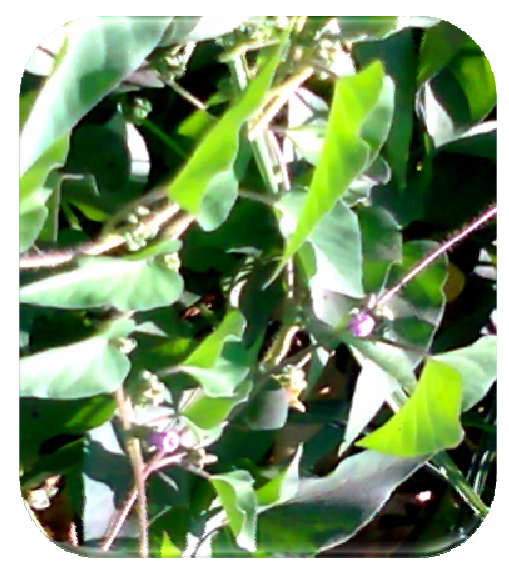

Fig. 1: A photo of the plant

x 0.625

\section{Material}

Fresh samples of Ipomoea eriocarpa leaves, stems, seeds and fruits, were collected

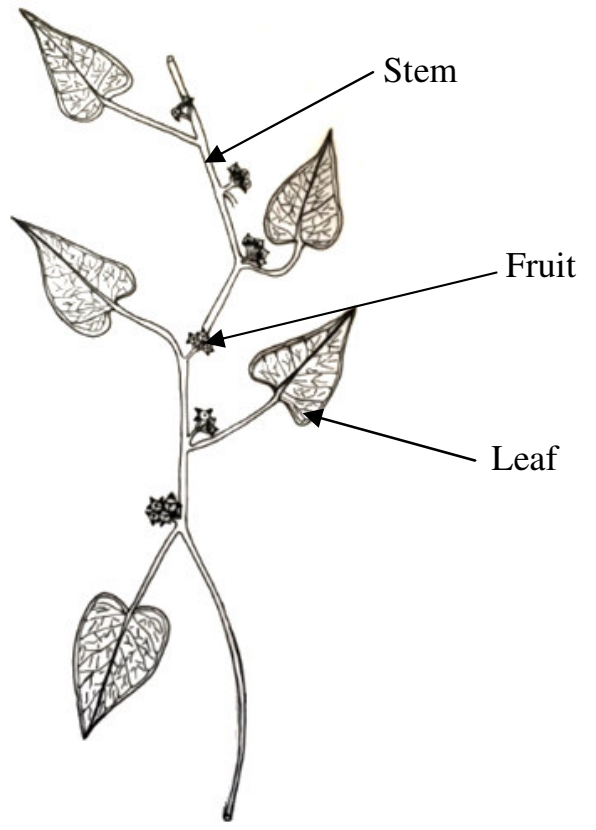

Fig. 2:

(A)

A) Macromorphology of the aerial parts of the plant

B) Macromorphology of the leaf. during the flowering stage in the period from October to November 2012 from North West desert $100 \mathrm{Km}$. from Sohag. The plant was identified and authenticated by Dr. Salah ElNaggar, Prof. of Plant Taxonomy, Faculty of Science, Assiut university. Voucher specimen no. (IE-11-2012) has been kept in the herbarium of Pharmacognosy department, Faculty of pharmacy Assiut university. Different organ samples were preserved in mixture of alcohol (70\%):glycerin: water $(1: 1: 1)$ and stored in a tightly closed container. For microscopical study of the powder, each organ of the plant was separately air-dried and reduced to fine powder.

\section{The leaf}

\section{A- Macromorphology}

The leaves (Figs. 2A\&2B) are simple, alternate, exstipulate and petiolate with upper green surface being paler in the lower one. The lamina is cordate in shape with entire margin, symmetric base and acuminate apex. It measures (4- 8.5-11) in length and about (0.73.9-5.6) $\mathrm{cm}$ in width. The venation is pinnately reticulate. It is hairy on both surfaces. The petiole is long, cylindrical and pale green in colour measure about (3.6-4.4-6.7) $\mathrm{cm}$ in length and $(0.3-0.5-0.7) \mathrm{cm}$ in diameter. The leaf is odourless and has a slightly bitter taste.

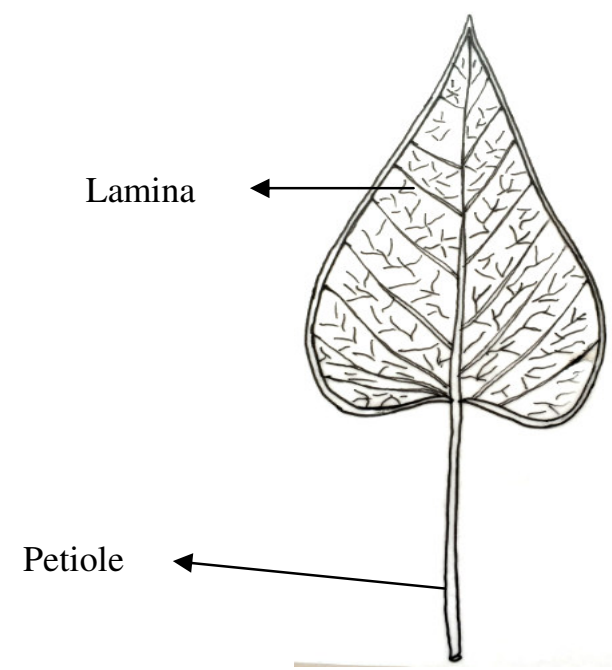

(B) 


\section{B- Micromorphology \\ 1- The lamina}

The transverse section in the lamina (Fig. 3A) appears more or less biconvex in outline with the midrib is more prominent on the lower surface. It shows a dorsiventral structure. The palisade is interrupted in the midrib region by mass of collenchyma, another small mass of collenchyma is present abutting on the lower epidermis. The midrib shows crescent shape bicollateral vascular bundle, having lower arc of pericycle.

Both the upper and lower epidermises are covered with few glandular and abundant nonglandular hairs which increase in number over the midrib region.

\section{The epidermis Upper epidermis}

It consists of one row of tangentially elongated cells as seen in transverse section (Figs. 3B\&4). In surface view (Fig. 3C) appear polygonal, isodiametric to subrectangular slightly elongated with nearly straight anticlinal walls covered with moderately thick striated cuticle. Stomata of paracytic type are present. Trichomes are present of both covering and glandular types. The covering trichomes are usually unicellular sometimes bicellular and covered with smooth cuticle. The covering trichomes are very long with acuminate apex. Few glandular hairs are present, with globular multicellular head, from 2 to 6 cells with unicellular stalk. The upper epidermis is showing cicatrices of hairs.

\section{Lower epidermis}

It consists of one row of tabular to square cells as seen in transverse section (Figs. 3B\&4). In surface view (Fig. 3D) the cells are polygonal, mostly isodiametric with wavy anticlinal walls. They are covered with relatively moderately thick striated cuticle. Numerous rounded to oval stomata of the paracytic type are present. The trichomes are similar to those of the upper epidermis in all aspects.

\section{Neural epidermis}

In surface view (Fig. 3E), the neural epidermal cells appear as longer, axially elongated cells with more straight anticlinal wall. Covered with smooth cuticle and showing cicatrices of hair.

\section{The mesophyl}

The leaf (Fig. 3B) shows a dorsiventral structure with mesophyl differentiated into a palisade and spongy tissue. The palisade is formed of two rows of radially elongated cylindrical columnar cells containing chloroplasts, the upper one is longer than the inner one. The spongy tissue is formed of thin walled rounded to oval chlorenchymatous cells showing clusters of calcium oxalate.

\section{The midrib}

\section{The cortical tissue}

The cortical tissue (Fig. 4) consists of cellulosic rounded to oval parenchymatous cells containing starch granules and clusters of calcium oxalate mainly at the lower part. The starch is mainly simple sometimes compound, spherical to oval in shape with faint centric slitshaped hilum appearing in large one. A hypodermal zone of several rows of collenchymatous cells is abutting on both epidermises. The endodermis is indistinct.

\section{The vascular tissue}

The pericycle (Fig. 4) is represented by a lower arc of nearly two rows of thin walled parenchymatouse cells below the vascular bundle.

The vascular bundle (Fig. 4) is bicollateral vascular bundle consisting of radiating xylem and phloem. The cambium is not differentiated (Figs. 4\&7).

The xylem (Fig. 4) consists mainly of lignified vessels regularly arranged in radial rows of spiral, reticulate sometimes scalariform thickenings (Fig. 7). The xylem fibres are few, showing moderately thickened, slightly lignified walls with tapering pointed ends (Fig. 7). The medullary rays are usually uniseriate sometimes biseriate and formed of radially elongated thin-walled parenchyatous cells.

The phloem (Fig. 4) consists of soft elements, which are formed of sieve tubes, companion cells and phloem parenchyma which containing small cluster crystals of calcium oxalate. 

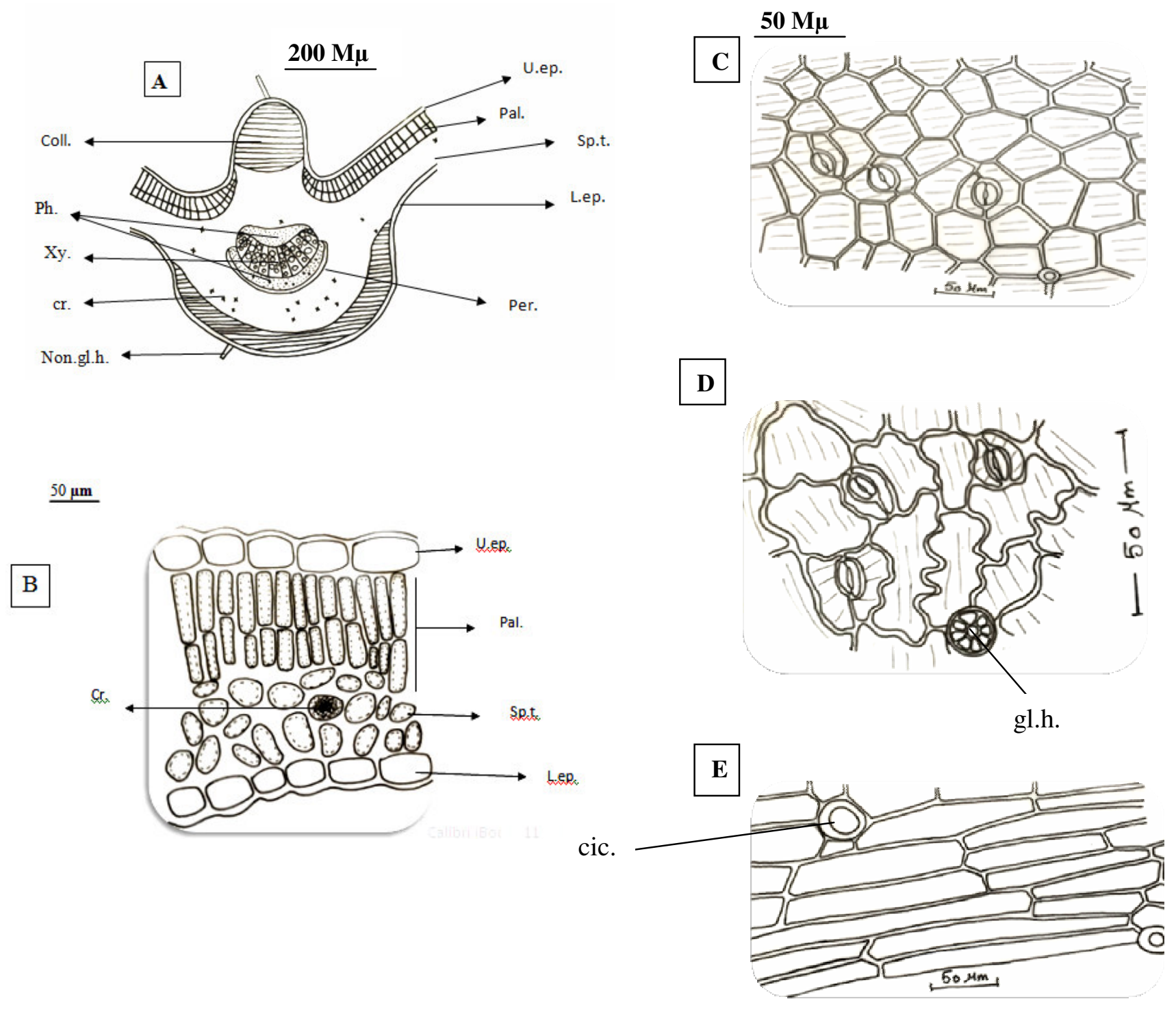

Fig. 3:

A) The diagrammatic T.S. of the leaf.

B) The detailed T.S. in the lamina.

C) The upper epidermis of the leaf.

D) The lower epidermis of the leaf.

E) The neural epidermal cells of the leaf.

cic., cicatrix; coll., collenchyma; cr., cluster of calcium oxalate; gl.h., glandular hair; 1.ep., lower epidermis; non.gl.h., non glandular hair; pal., palisade cells; per., pericycle; ph., phloem; sp.t., spongy tissue; u.ep., upper epidermis; xy., xylem. 

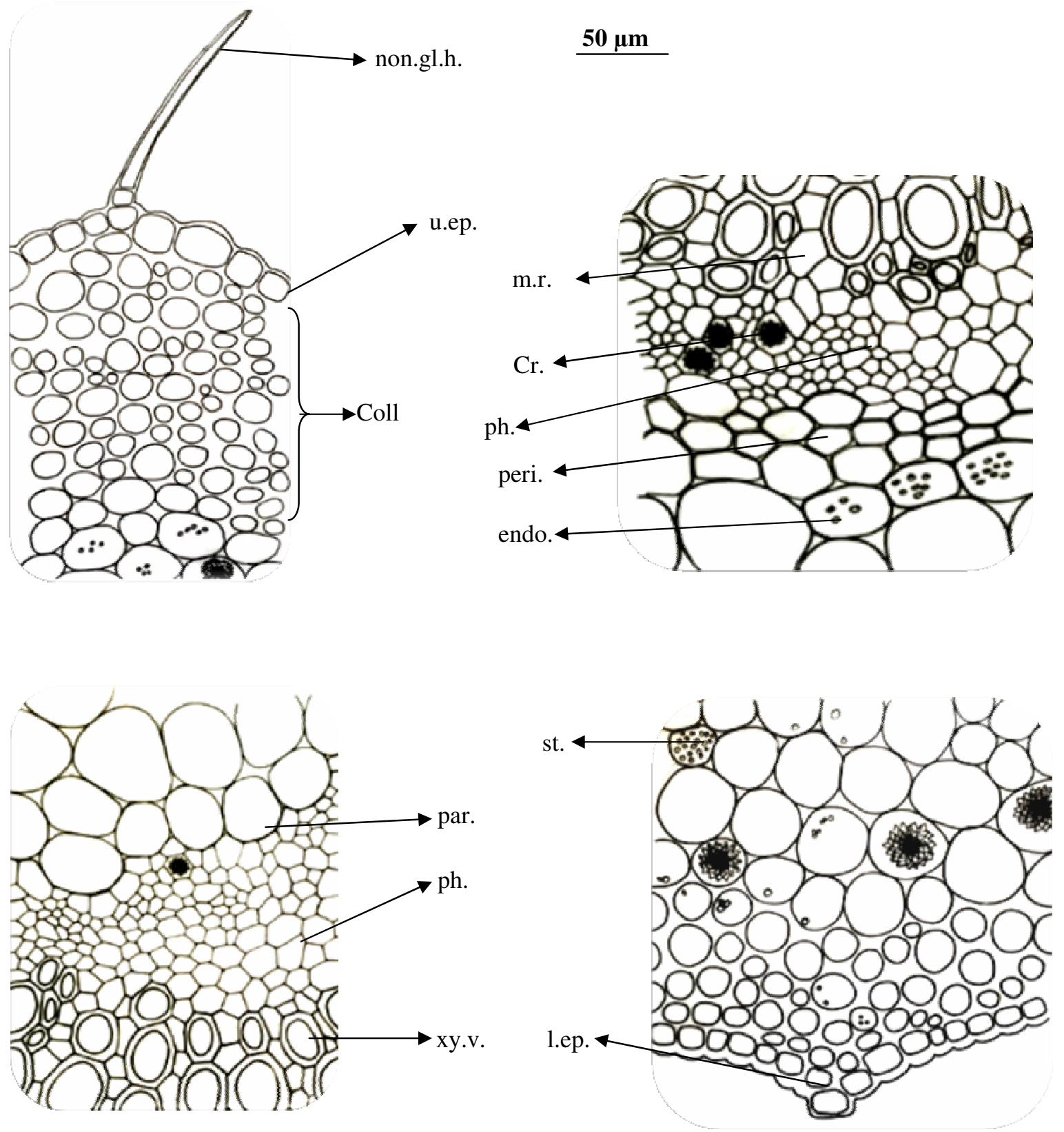

Fig. 4: The detailed T.S. in the midrib region of the leaf.

coll., collenchyma; cr., cluster of calcium oxalate; endo., endodermis; l.ep., lower epidermis; m.r., medullary rays; non.gl.h., non glandular hair; par., parenchyma; peri., pericycle; ph., phloem; st., starch; u.ep., upper epidermis; xy.v., xylem vessels. 


\section{2- The petiole}

The transverse section of the petiole (Fig. 5A) appears more or less rounded in outline, showing two small ridges on upper side with shallow groove in between, It shows an epidermis carrying numerous non-glandular hairs and a cortical tissue formed of hypodermis layer which contain starch granules followed by collenchymatous zone and wide parenchymatous cortex. The vascular system is formed of a main crescent-shaped collateral vascular bundle in addition to two subsidiary smaller collateral vascular bundles corresponding to the two ridge. The endodermis being below the vascular bundles.

\section{The epidermis}

The epidermis (Fig. 6) consists of one row of rectangular to subrectangular cells. In surface view (Fig. 5B), they are polygonal mostly axially elongated with straight, relatively beaded anticlinal walls covered with moderately thick cuticle. Numerous covering trichomes and rarely glandular type are present which are similar to those of the lamina. Stomata are rare and if present, they are of the paracytic type and similar to those of lamina in shape and size.

\section{Hypodermis}

The hypodermis (Fig. 6) consists of one to two layers of spherical to hemispherical parenchymatous cells which contain starch granules.

\section{The cortical tissue}

The cortical tissue (Fig. 6) consists of three to five rows of rounded to oval collenchymatous cells is abutting on the epidermal surface, followed by several rows of rounded to oval thin-walled parenchymatous cells containing oval to rounded starch granules, prisms and cluster crystals of calcium oxalate. The endodermis is represented by a lower arc of nearly tabular elongated cells containing starch granules.

\section{Vascular tissue}

The pericycle (Fig. 6) is represented by a lower arc of nearly two rows of thin walled parenchymatous cells below the vascular bundle. The vascular bundle (Fig. 6) is large collateral crescent shaped, consisting of radiating xylem and phloem. The xylem and phloem are the same as mentioned in the lamina, but the petiole contain small groups of intraxylary phloem (Fig. 6) which consists of soft elements present above the vascular bundle containing starch granules and small cluster crystals of calcium oxalate.

\section{The powdered leaf}

It is dull green in colour with no odour and slightly bitter taste. It is characterized microscopically by the presence of the following (Fig. 7):

1- Fragments of upper epidermal cells show rubiaceous (paracytic) stomata.

2- Fragments of lower epidermal cells carrying numerous oval to rounded stomata of paracytic type.

3- Few glandular trichomes and numerous non-glandular trichomes.

4- Fragments of epidermal cells of the neural veins showing cicatrices of covering trichomes.

5- Fragments of epidermal cells of the petiole, with straight beaded anticlinal walls covered with smooth moderately thick cuticle.

6- Fragments of palisade cells.

7- Presence of scattered prisms and cluster crystals of calcium oxalate.

8- Fragments of lignified reticulate, scalariform and spiral xylem vessels.

9- Fragments of xylem fibres with lignified walls, wide lumina and tapering ends.

10- Scattered starch granules, which are simple, sometimes compound, rounded to oval in shape and showing faint centric slit-shaped hilum appearing in large one. 

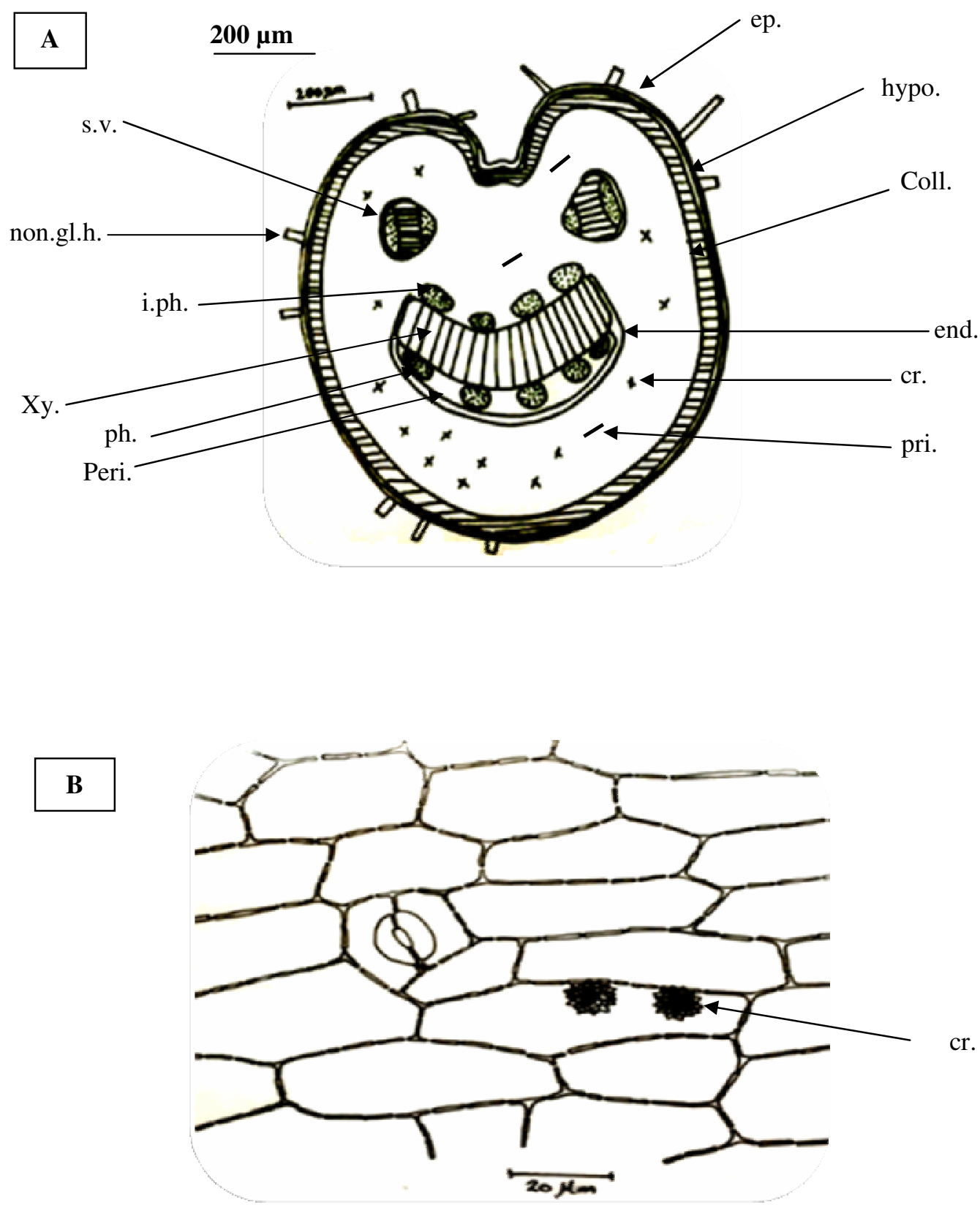

Fig. 5:

A) The diagrammatic T.S. of the petiole.

B) The epidermis of the petiole.

coll., collenchyma; cr., cluster of calcium oxalate; end., endodermis; ep., epidermis; hypo., hypodermis; i.ph., intraxylary phloem; non.gl.h., non glandular hair; peri., pericycle; ph., phloem; pri., prisms; s.v., subsidiary vascular bundle; xy., xylem. 

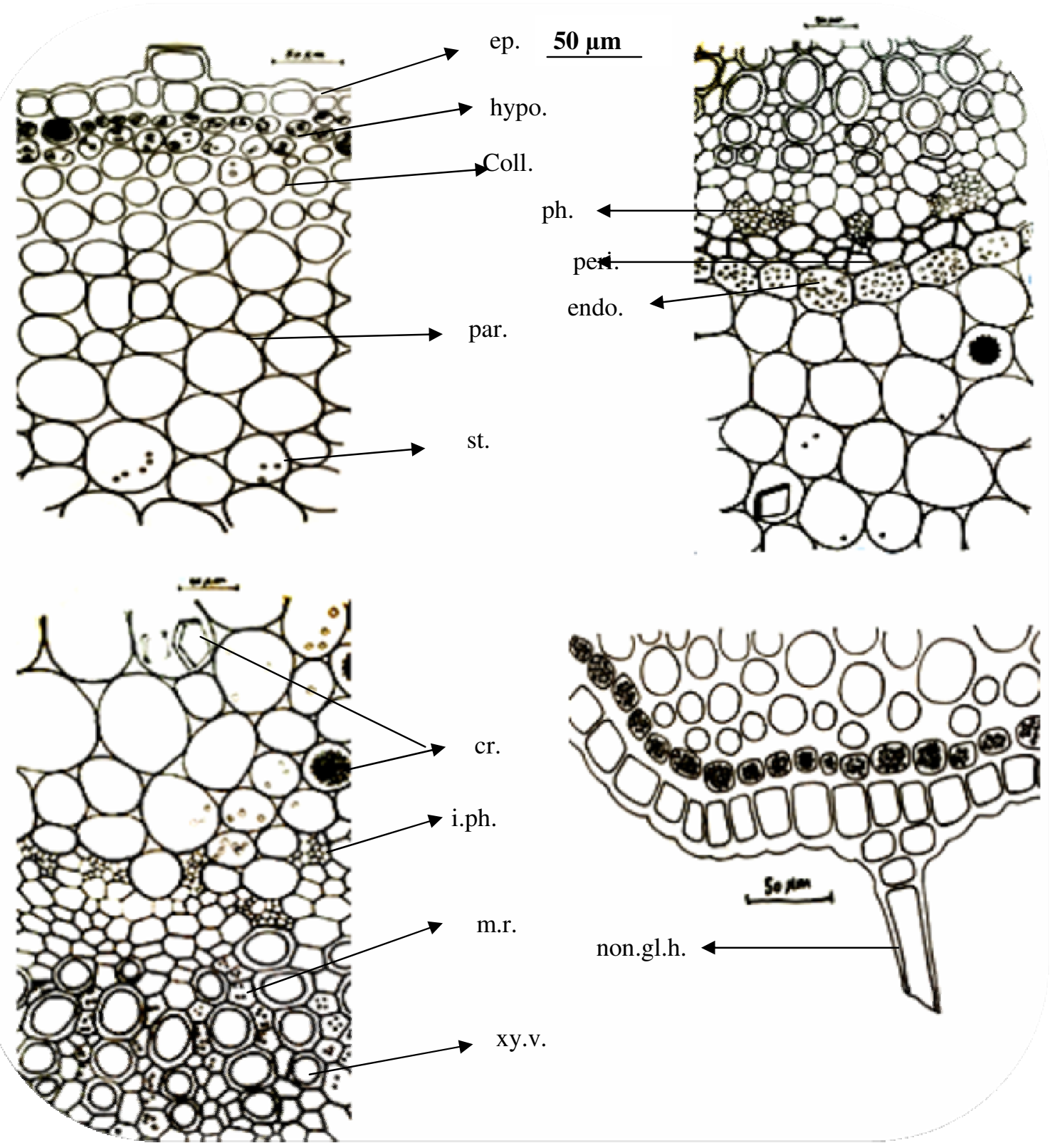

Fig. 6: The detailed T.S. in the petiole.

coll., collenchyma; cr., crystals of calcium oxalate; end., endodermis; ep., epidermis; hypo., hypodermis; i.ph., intraxylary phloem; m.r., medullary rays; non.gl.h., non glandular hair; par., parenchyma; peri., pericycle; ph., phloem; st., starch granules; xy.v., xylem vessels. 

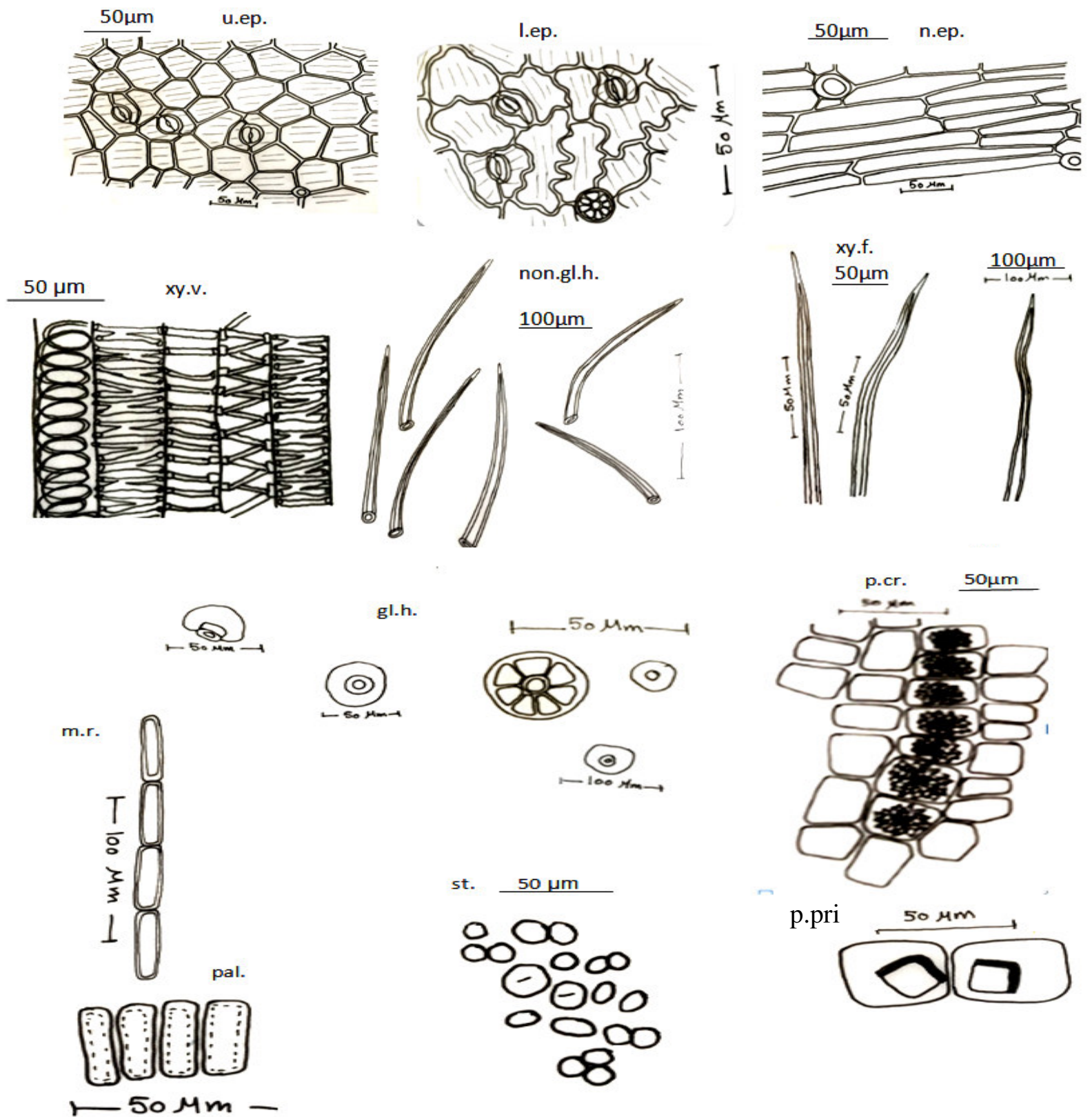

Fig. 7: Powder of the leaf.

ep.pet., epidermis of petiole; gl.h., glandular hair; l.ep., lower epidermis; m.r., medullary ray; n.ep., neural epidermis; non.g.h., non glandular hair; pal., palisade cells; p.cr., parenchyma contain cluster of calcium oxalate; p. pri., parenchyma contain prisms of calcium oxalate; st., starch granules; u.ep., upper epidermis; xy.f., xylem fibres; xy.v., xylem vessels. 
Table 1: Microscopical measurements of the leaf of Ipomoea eriocarpa R.Br. (In microns).

\begin{tabular}{|c|c|c|c|c|}
\hline Item & Length & Width & Diameter & Height \\
\hline \multicolumn{5}{|c|}{ Lamina } \\
\hline Upper epidermis & $31.8-45.5-68.1$ & $13.6-27.3-50$ & $15.4-19.2-23$ & $11.5-19.2-23$ \\
\hline Lower epidermis & $23.3-\underline{35}-41.6$ & $10-\underline{16.6-28.3}$ & 7.7-15.4-23.1 & 7.6-15.4-23 \\
\hline Neural epidermis & $104.2-145.8-208.3$ & $8.3-12.5-25$ & & \\
\hline Stomata & $18.1-22.7-27.3$ & & $4.5-\underline{9}-13.6$ & \\
\hline Palisade cells & $20.8-54.2-62.5$ & $12.5-16.7-20.8$ & & \\
\hline Parenchyma & & & $23-\underline{30.8-53.8}$ & \\
\hline Collenchyma & & & $7.7-19.2-26.9$ & \\
\hline Clusters & & & 15.4-19.2-30.8 & \\
\hline Starch & & & $2.6-3.5-3.8$ & \\
\hline Xylem vessels & & & 26.9-34.6-38.5 & \\
\hline Xylem fibres & 954-1136-1227 & $7.7-15.4-23$ & & \\
\hline Glandular hair & $13.3-20-23.3$ & $13.3-\underline{26.7-30}$ & & \\
\hline Non- glandular hair & $250-373.5-375$ & $15.6-\underline{25-37.5}$ & & \\
\hline Medullary rays & $91.7-\underline{100-116.7}$ & $16.7-\underline{25-33.3}$ & & \\
\hline \multicolumn{5}{|c|}{ Petiole } \\
\hline Epidermis & $62.5-12-137.5$ & $18.75-\underline{31.3}-43.8$ & $15.4-19.2-23$ & $\begin{array}{c}11.5-15.4- \\
19.2 \\
\end{array}$ \\
\hline Parenchyma & & & 26.9-42.3-53.8 & \\
\hline Collenchyma & & & $3.8-\underline{11.5}-19.2$ & \\
\hline Clusters & & & $11.5-15.3-19.2$ & \\
\hline Prisms & & & 15.4-19.2-23.1 & \\
\hline Starch & & & $2.6-3.5-3.8$ & \\
\hline Xylem vessels & & & 26.9-34.6-38.5 & \\
\hline
\end{tabular}

\section{The stem}

\section{A- Macromorphology of stem}

The stem (Fig. 8A) is cylindrical, herbaceous, twining and prostrate, greenish brown when fresh becoming greyish brown when dry. It is monopodially branched and pubescent. It has long internodes, The fracture is short and yellow in colour. It is odourless with a slightly bitter taste.

\section{B- Micromorphology}

The transverse section in the stem, (Fig. $8 \mathrm{~B})$ is more or less circular in outline. It shows hairy epidermis, followed by hypodermis consists of one to two layers of spherical to hemispherical cells which contain starch granules followed by parenchymatous cortex with outer zone of collenchyma. The endodermis is indistinct. The pericycle is parenchymatous interrupted by large patches of shining non lignified pericyclic fiber. The vascular system is formed of collateral vascular bundles varying in size and separated by medullary rays. The pith is hetergenous, wide parenchymatous with groups of intraxyllary phloem at its periphery. Starch granules and few cluster crystal of calcium oxalate are present in the parenchyma of the cortex and pith.

\section{Epidermis}

The epidermis (Fig. 9) consists of one row of square to subrectangular tangentially elongated cells in side view. In surface view (Fig. 10), the cells are polygonal, axially elongated with more or less straight anticlinal walls. They are covered with moderately striated cuticle and showing oval to rounded stomata of the paracytic type, which are very few. The epidermis carries numerous long nonglandular trichomes. The hairs are unicellular sometimes bicellular, with acuminate apices and covered with smooth cuticle. 


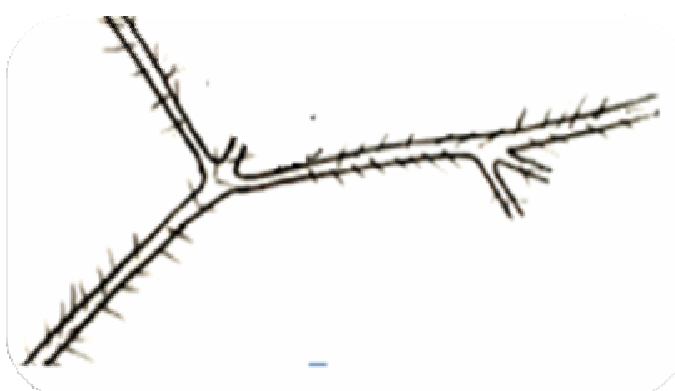

(A)

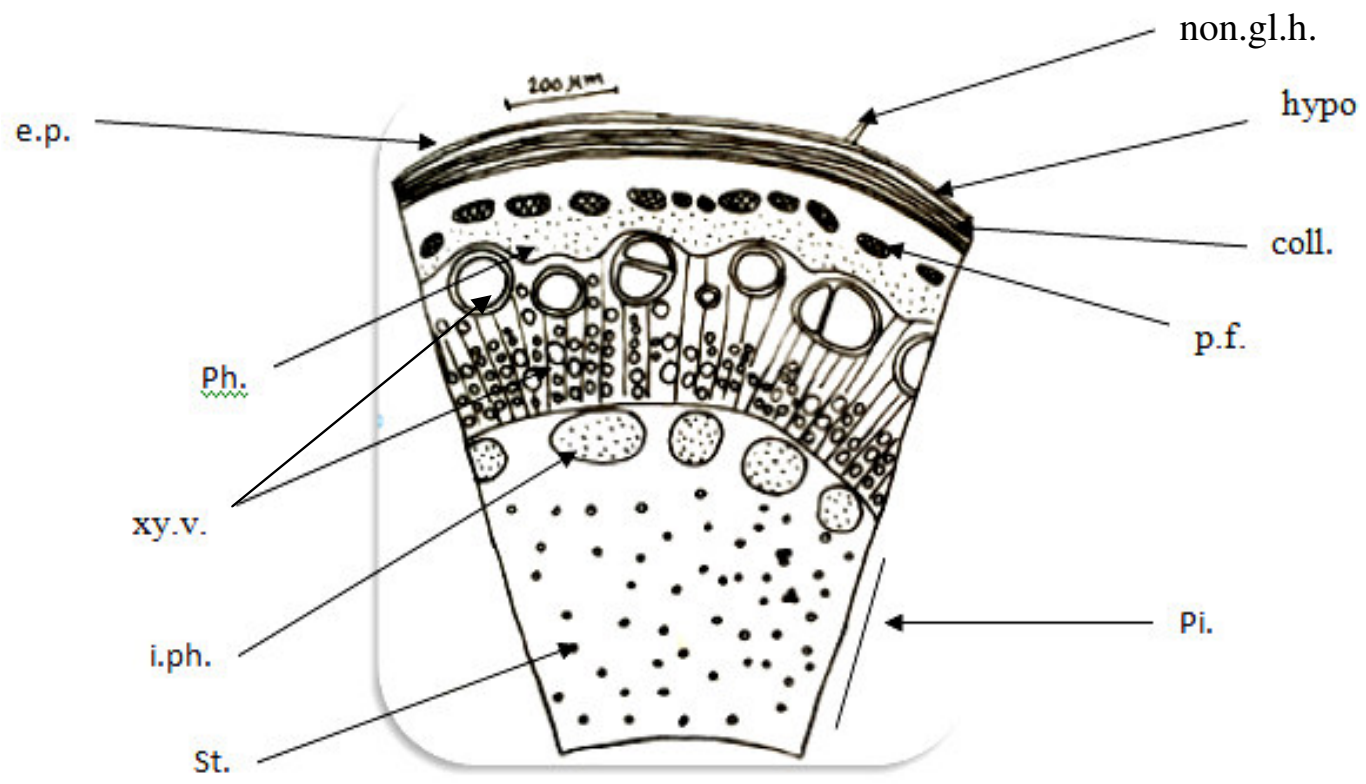

(B)

Fig. 8:

A) Macromorphology of the stem

x 0.8

B) The diagrammatic T.S. of the stem.

coll., collenchyma; cr., cluster crystals of calcium oxalate; ep., epidermis; hypo., hypodermis i.ph., intraxylary phloem; non.gl.h., non glandular hairs; p.f., pericyclic fiber; ph., phloem; pi., pith; st., starch granules; xy.v., xylem vessels. 


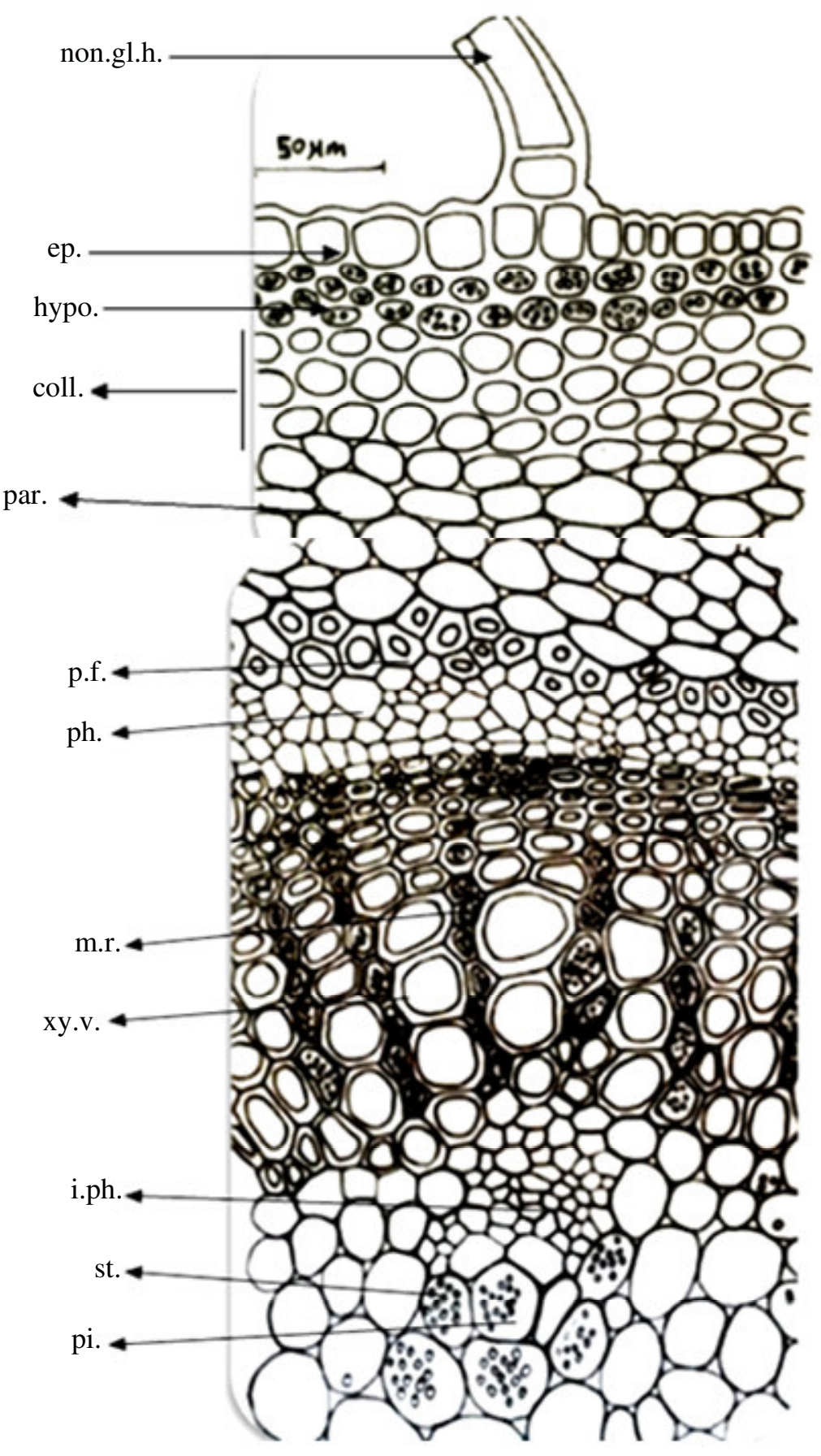

Fig. 9: The detailed T.S in the stem.

coll., collenchyma; ep., epidermis; hypo., hypodermis; i.ph., intraxylary phloem; m.r., medullary rays; non.gl.h., non glandular hairs; par., parenchyma; ph., phloem; p.f.; pericyclic fiber, pi., pith; st., starch granules; xy.v., xylem vessels. 


\section{The hypodermis}

The hypodermis (Fig. 9) consists of one to two rows of spherical to hemispherical parenchymatous cells which contain starch granules.

\section{The cortex}

The cortex (Fig. 9) is relatively narrow consisting of three to four outer rows of collenchymatous cells being rounded to oval in shape and have thick cellulosic walls, followed by parenchymatous cells which are rounded to oval in shape containing starch granules, which are rounded to oval in shape with centric slitshaped hilum. The endodermis is indistinct.

\section{The vascular system}

The pericycle (Fig. 9) exhibits zone of parenchymatous cells which interrupted by a continous ring of non lignified pericyclic fibres. The fibers are moderately thick and have non lignified walls with relatively wide lumina.

The central stele (Fig. 9) is formed of wide continous ring of collateral vascular bundles separated by narrow medullary rays of one cell in width. The cambium is indistinct.

The phloem (Fig. 9) is formed of a narrow ring, consisting of shining thin walled soft, cellulosic elements of sieve tubes, companion cells and thin walled parenchymatous cells.

The xylem (Figs. 9\&10) is formed of wide zone of radiating elements showing wide lignified vessels, fibres and tracheids. The vessels are thick lignified walls and have spiral, reticulate and pitted thickening. The xylem fibres have tapering; pointed ends, wide lumina with thickened and lignified walls.The tracheids (Fig. 10) are formed of elongated, pitted, thickened, lignified walls and have blunt ends.

The medullary rays (Fig. 9) are usually one to two cells in width, formed of radially elongated polygonal cells with thin lignified walls containing starch granules which are similar to those in the leaf.

Intraxylary phloem (Fig. 9) consists of scattered large groups of small soft elements present at the periphery of the pith.

The pith (Fig. 9) is wide, consisting of rounded to oval parenchymatous cells containing starch granules and cluster crystals of calcium oxalate.

\section{The powdered stem}

It is pale yellowish-grey in colour, with no characteristic odour and slight bitter taste. It is characterized microscopically by the presence of the following (Fig. 10):

1- Fragments of the epidermal cells showing fewer number of paracytic stomata.

2- Numerous non-glandular trichomes.

3- Fragments of non-lignified pericyclic fibers, having thin walls, narrow lumina and pointed acuminate ends.

4- Fragments of lignified spiral, pitted and reticulate xylem vessels.

5- Fragments of tracheids showing lignified and pitted walls.

6- Fragments of xylem fibres, which have thick lignified wall moderately wide lumina and blunt ends.

7- Fragments showing lignified pitted xylem parenchyma.

8- Numerous globular to oval starch granules, which are usually simple, with central slitshaped hilum.

\section{Macro- and micromorphological study of the seed}

\section{A- Macromorphology}

The seed (Fig. 11A) is small, dark black in colour when fresh and grey in colour when dry measuring $(0.2-0.3-0.4) \mathrm{cm}$ in length and $(0.5-$ $\underline{0.6}-.0 .7) \mathrm{cm}$ in width. It is usually three sided, with two flat ventral surfaces, have a central depression and one convex dorsal surface. The micropyle and hilum are present in the central depression of the ventral surface. The raphe is represented by raised ridge which extends from the base to the apex of the seed. The seed is hard, tastless and odourless. Transverse section of the seed shows albuminous seed. The embryo is large spirally folded. The endosperm is small which traverse inbetween the folds of embryo as in transverse cut (T.C) and longitudinal cut (L.C) (Fig. 11B,11C). In the region of the raphe this layer becomes narrow, and embedding a small vascular strand.

The embryo (Fig. 11B,11C) is formed of two large leafy and easily longitudinally separaple cotyledons. Each cotyledon is bent backward towards the radical then fore ward again. 


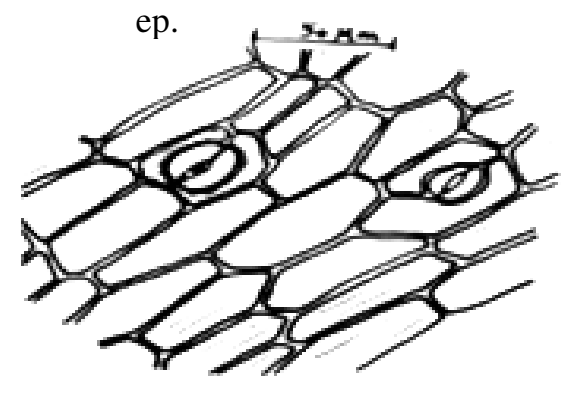

A. A. Khalifa, et $\underline{\text { al. }}$
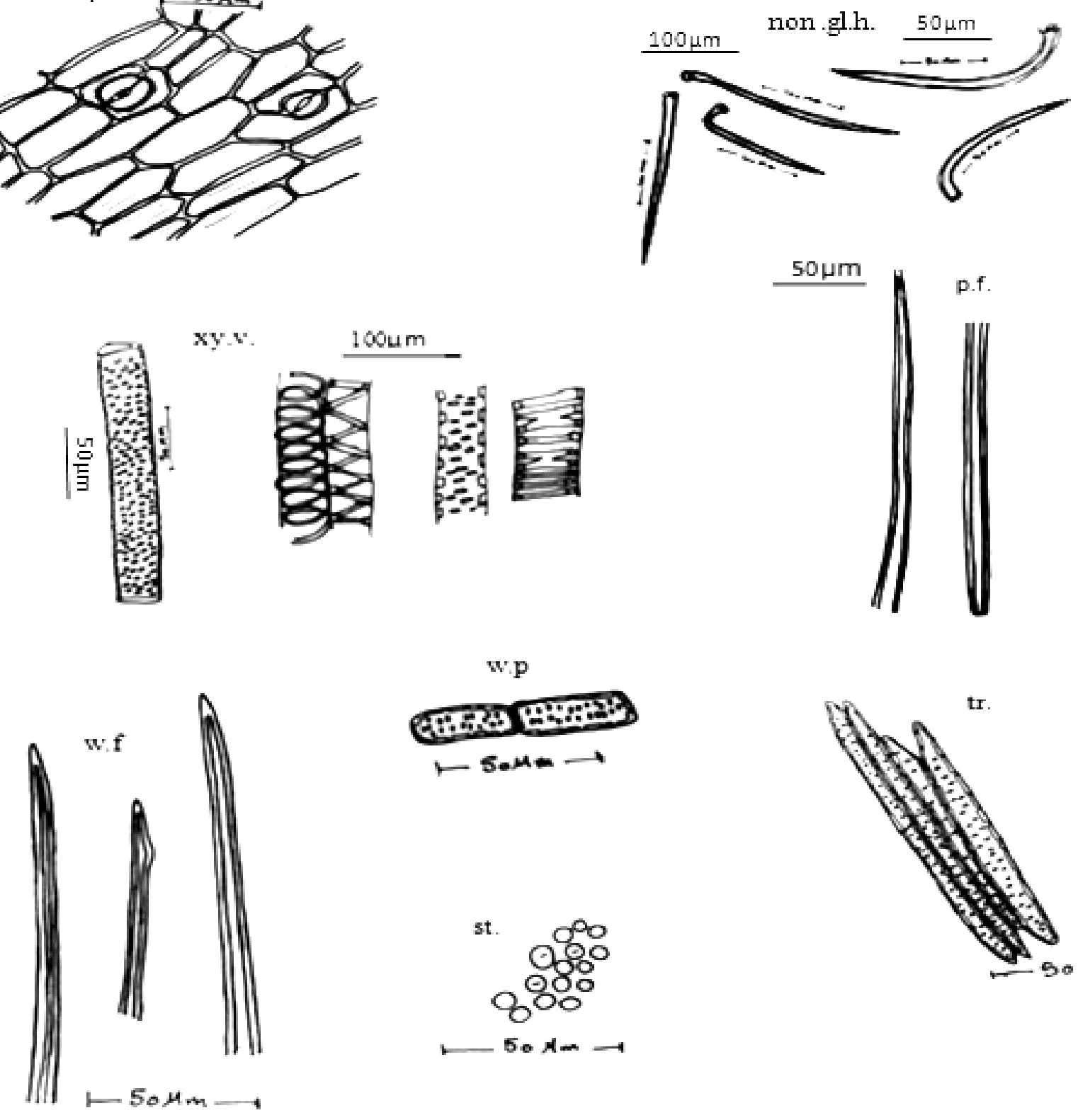

Fig. 10: Powder of the stem.

ep., epidermis; non.gl.h.: non-glandular hairs; p.f., pericyclic fibres; st., starch granules; tr., tracheids; w.f., wood fibres; w.p., wood parenchyma; xy.v, xylem vessels.

Table 2: Microscopical measurements of the stem of Ipomoea eriocarpa R.Br. (In microns):

\begin{tabular}{||l|c|c|c|c||}
\hline \multicolumn{1}{|c|}{ Item } & Length & Width & Diameter & Height \\
\hline Epidermal cells & $32.1-53.6-64.3$ & $10.7-17.9-21.4$ & $3.5-21.4-25$ & $17.8-21.4-25$ \\
\hline Stomata & $14.3-17.9-21.4$ & & $10.7-14.3-17.8$ & \\
\hline Collenchyma & & & $7.1-10.7-23.1$ & \\
\hline Parenchyma & & & $21.4-\underline{32.1}-39.3$ & \\
\hline Pericyclic fibers & $428.5-\underline{500}-571$ & & $7.1-\underline{10.7-14.2}$ & \\
\hline Xylem vessels & & & $27.7-\underline{33.3}-44.4$ & \\
\hline Wood parenchyma & $30.9-\underline{35.7-45.2}$ & $7.1-\underline{9.5}-11.9$ & & \\
\hline Wood fiber & $7894-947.3-999$ & & $6.8-9-11.4$ & \\
\hline Medullary rays & $17.9-21.4-39.3$ & $10.7-17.9-21.4$ & & \\
\hline Tracheids & $60-\underline{70}-90$ & $2-\underline{4}-8$ & & \\
\hline Starch & & $2.1-\underline{4} .2-6.3$ & \\
\hline Non.glandular hair & $111-\underline{122.2-138.9}$ & $5.5-11.1-16.7$ & & \\
\hline \hline
\end{tabular}



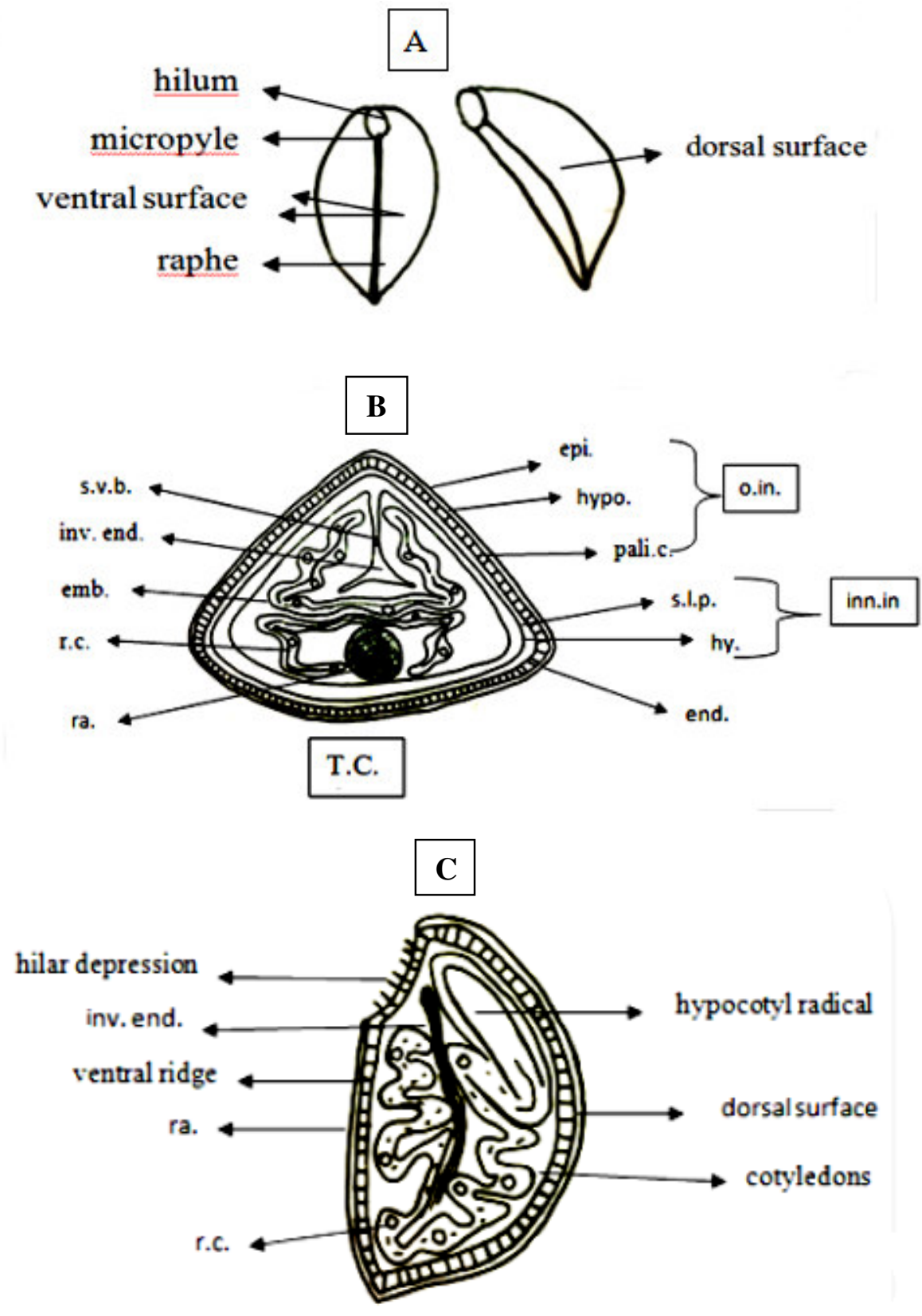

L.C.

Fig. 11:

A) Macromorphology of the seed.

x 8.3

B) Transverse cut of the seed.

C) longitudinal cut of the seed.

emb., embryo; end., endosperm; epi., epidermis of testa; hy., hyaline layer; hypo., hypodermis; inn.in., inner integument; inv.end., invaginated collapsed endosperm; o.in., outer integument; pali., palisade like cells; ra., radicle; r.c., resin cells; s.l.p., slightly lignified parenchyma; s.v.b., small vascular bundle of raphe. 


\section{B- Micromorphology}

A transverse section in the seed, (Fig. $12 \mathrm{~A}$ ) is more or less triangular in outline. It shows testa, endosperm and embryo.

The testa is formed of two integuments. The outer one consists of an outer epidermis, followed by a hypodermis layer and a layer of palisade-like cells. The inner integument is formed of an outer slightly lignified parenchymatous zone followed by a hyaline layer.

\section{The outer integument \\ a. The epidermis}

The epidermis (Fig. 12A) is formed of more or less tabular tangentially elongated cells. In surface view (Fig. 13), they appear polygonal to isodiametric with cellulosic, wavy anticlinal walls.

\section{b. The hypodermis}

The hypodermis (Figs. 12A\&13) is formed of one layer of small elongated cells which have u-shape cellulosic like thickening.

\section{c. The palisade like cells}

The palisade like cells (Figs. 12A\&13) is formed of two rows of radially elongated cells with thick cellulosic walls and narrow lumina. Top and basal view of palisade like cells (Fig. 13) appearing polygonal cells in outline, with sharp angles and narrow lumina.

\section{The inner integuments}

The inner integument (Fig. 12A) is formed of an outer region of 2-3 layers of tangentially elongated parenchymatous cells with slightly lignified walls, followed by a hyaline layer.

\section{The endosperm}

The endosperm (Figs. 12A\&13) is formed of 3-5 layers of polygonal cells, with thick cellulosic walls. The cells contain aleurone grains and fixed oil globules.

\section{The embryo}

The embryo (Figs. 12A\&13) is formed of polyhedral parenchymatous cells, with thin cellulosic walls and full of aleurone grains and fixed oil globules sometimes contain small cluster crystals of calcium oxalate. The resin cells are scattered in the tissue of embryo; they are polygonal to rounded in shape, with suberized walls and filled with resin contents, which give yellow colour with iodine solution and dissolve in $90 \%$ ethyl alcohol.

\section{The powdered seed}

Powdered seed is grayish brown in color. It is odourless, with a slightly characteristic taste. The main diagnostic elements of powdered seed are (Fig. 13):

1- Fragments of the epidermis of the seed, being polygonal to isodiametric cells with cellulosic very wavy anticlinal walls.

2- Fragments of side view of palisade-like cells which have narrow lumina.

3- Top view of palisade like cells showing polygonal cells with sharp angle and straight anticlinal walls.

4- Occasional fragments of small lignified spiral vessels.

5- Fragment of endosperm, showing polygonal cells with thick cellulosic walls which contain fixed oil globules and aleurone grains.

6- Fragment of embryo, full of aleurone grains and fixed oil globules.

\section{Macro-and micromorphology of the fruit}

\section{A- Macromorphology}

The fruit, (Fig. 14A) is simple, dry, dehiscent septifragal capsule and derived from a superior ovary. It is green in colour, becoming brown on ripening measuring (0.5$0.7-0.9) \mathrm{cm}$ in length and $(0.6-0.8-1) \mathrm{cm}$ in diameter with short pedicle. It is subglobular in shape with pointed apex of remaining style and spherical base. The fruit shows five persistent sepals and contains four dark brown seeds. The pericarp is thin, warty, hairy with short fracture,odourless and tastless.

In transverse section, (Fig. 14C) the fruit shows two locules. Each locule contains two seeds.

In longitudinal section, (Fig. 14B) the fruit shows two locules. Each locule contains one seed, with basal placentation.

\section{B- Micromorphology}

A tansverse section in the pericarp, (Fig. 15) shows epicarp and endocarp enclosing in between the mesocarp, which formed of two layers. 

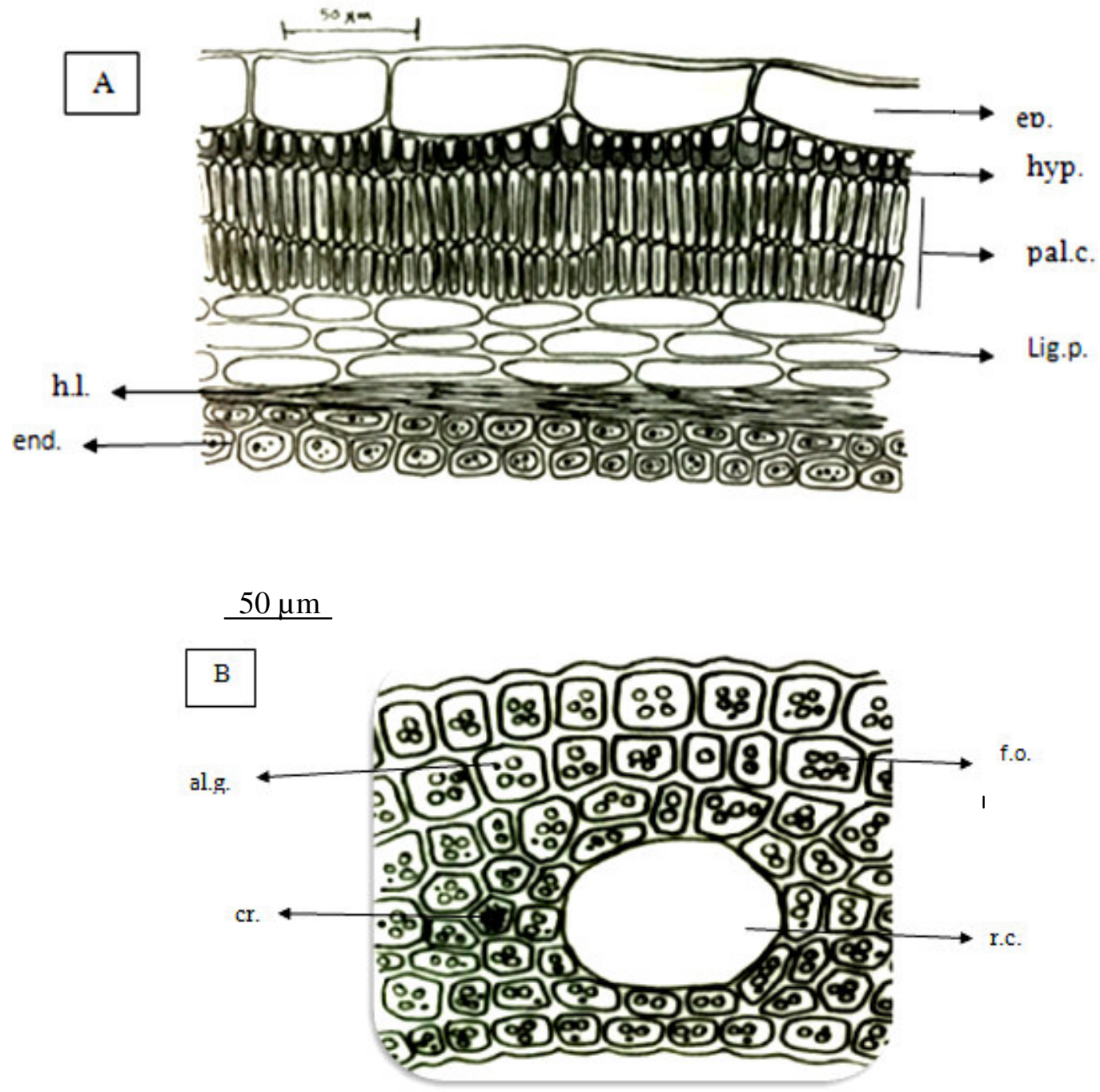

Fig. 12:

A) The detailed transverse section of the seed.

B) The detailed T.S. of the embryo.

end., endodermis; ep., epidermis of testa; h.l., hyaline layer; hyp., hypodermis; lig.p., lignified parenchyma; pal.c., palisade cells. al.g., aleurone grain; cr., cluster crystal of calcium oxalate; f.o., fixed oil; r.c., resin cell. 

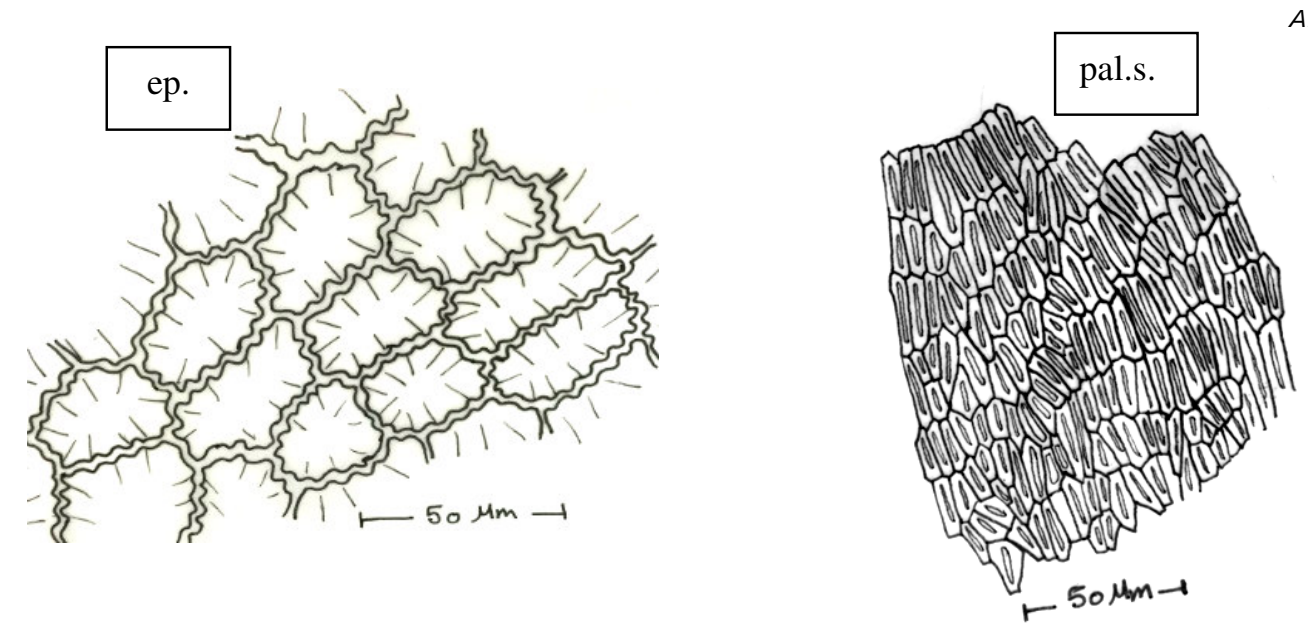

A. A. Khalifa, et al.
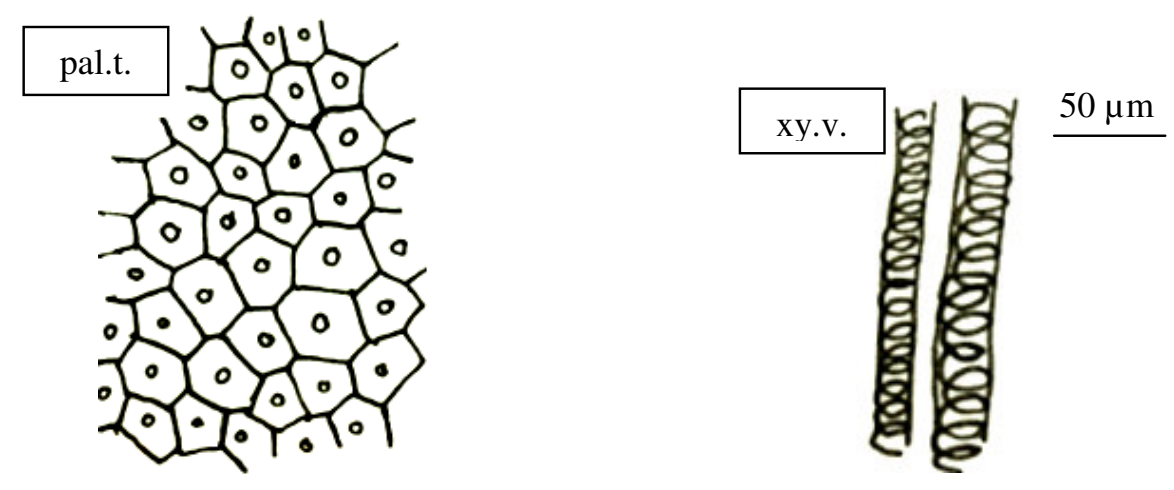

\section{$150 \mu m \rightarrow$}
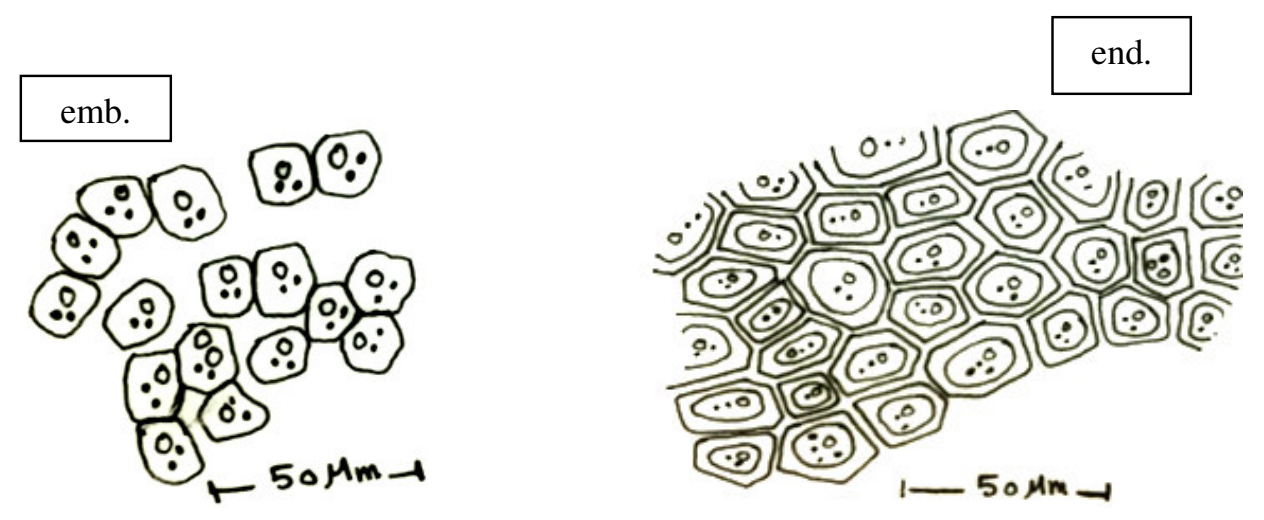

Fig. 13: Powder of the seed.

emb., embryo; end., endosperm; epi., epidermis of testa; pal.s., palisade cell side view; pal.t., palisade cell top view; xy.v., xylem vessel.

Table 3: Microscopical measurements of the seed of Ipomoea eriocarpa R.Br (In microns).

\begin{tabular}{|l|c|c|c|c|}
\hline \multicolumn{1}{|c|}{ Item } & Length & Width & Height & Diameter \\
\hline Epidermis of testa & $28.5-35.7-42.8$ & $14.3-16.7-26.2$ & $23.7-26.3-28.9$ & $44.7-47.4-50$ \\
\hline Hypodermis & $7.9-10.5-15.8$ & $2.6-5.3-8$ & & \\
\hline Palisade like cells & $15.8-23.7-26.3$ & $2.6-\underline{5.3-7.8}$ & & \\
\hline
\end{tabular}



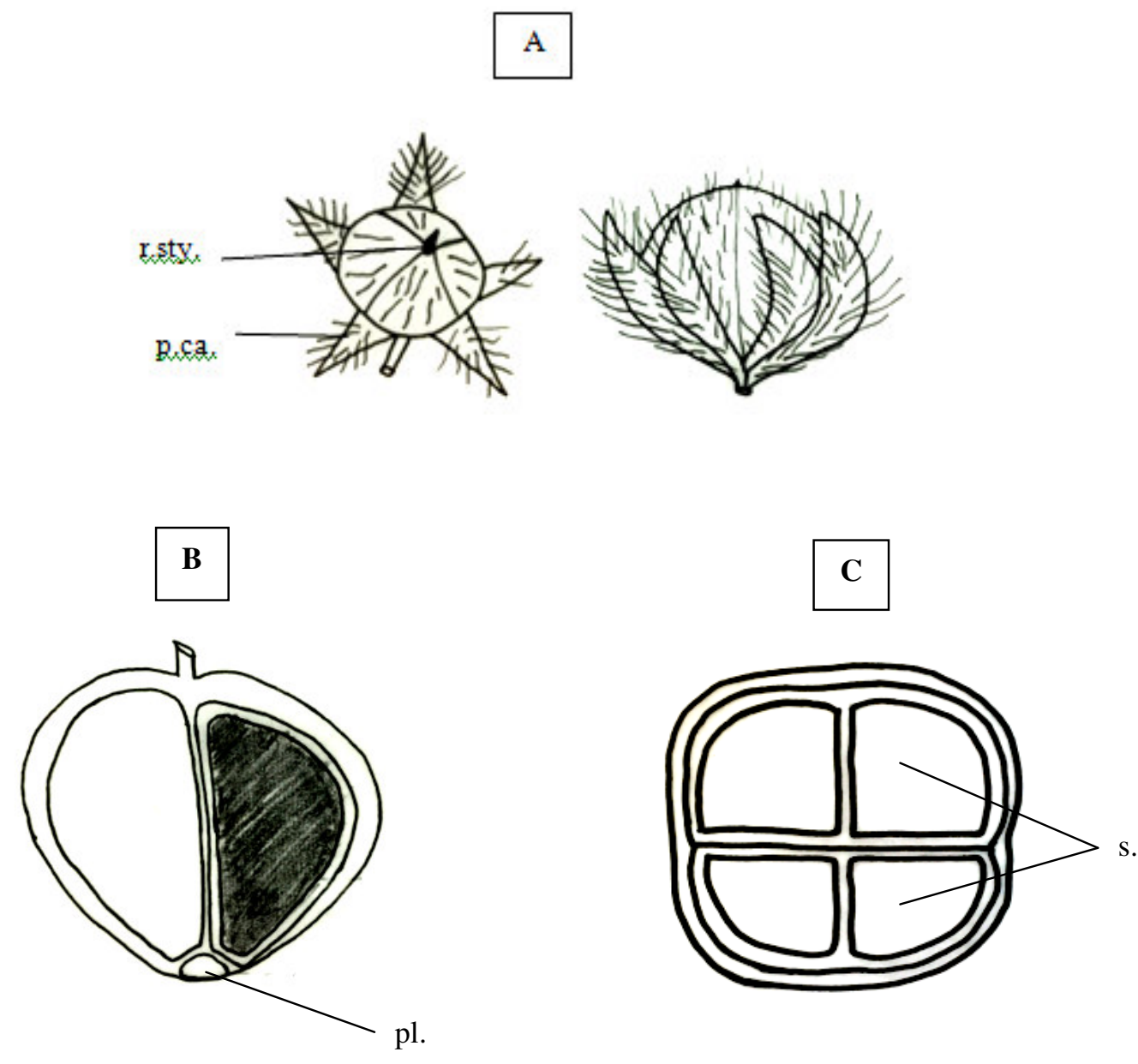

Fig. 14:

A) Macromorphology of entire fruit with persistent calyx. $\quad$ x 4.3

B) The longitudinal cut of the fruit.

C) The Transverse cut of the fruit.

p.ca., persistent calyx; pl., placenta; r.sty., remains of style; s., seed.

\section{The epicarp}

The epicarp, (Fig. 15) consists of one row of more or less tabular flattened cells. In surface view (Fig. 16), they are polygonal with almost straight anticlinal walls, covered with striated cuticle. Stomata are rarely present of paracytic type.

\section{The mesocarp}

The mesocarp, (Fig. 15) is formed of two layers, the outer one formed of thin walled slightly radially elongated parenchymatous cells of varying size with scattered polygonal resin cells. The inner layer of the mesocarp is formed of one row of scleriede cells which are radially elongated, heavily thickened walls with narrow lumina at the top, wide lumina at the base, followed by two rows of polygonal fibers have slightly thickened, lignified walls with wide lumina.

\section{The endocarp}

The endocarp, (Fig. 15) is formed of one row of more or less cubical to sub-rectangular cells with thin, non lignified walls. In surface view (Fig. 16), they are polygonal with straight anticlinal walls, covered with smooth cuticle. Stomata are absent. 


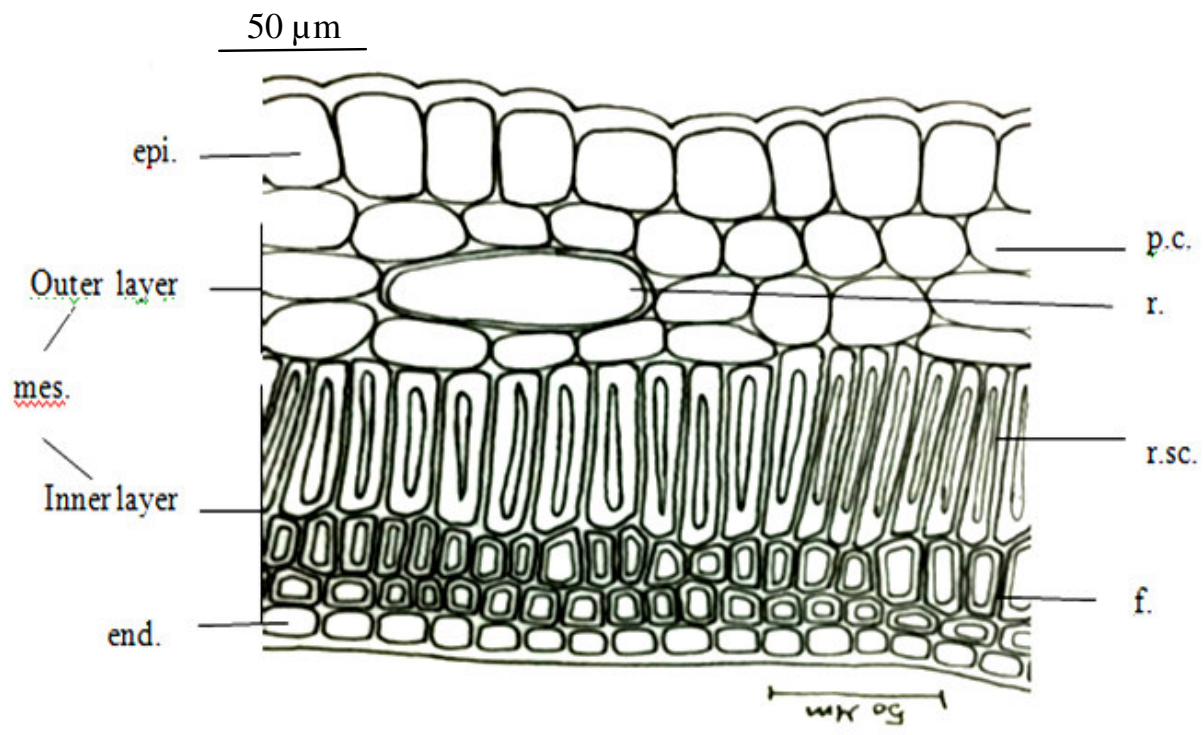

Fig. 15: Detailed transverse section of the fruit.

end., endocarp; epi., epicarp; f., fiber; mes., mesocarp; p.c., parenchymatous cells; r., resin; r.sc., radially elongated sclereids.

\section{Powdered fruit}

Powdered fruit is yellowish -green in colour, the main diagnostic elements of powdered fruit (Fig. 16) are:

1- Fragments of epicarp, showing more or less flattened polygonal cells with almost straight anticlinal walls, covered with striated cuticle and rarely showing stomata of paracytic type.

2- Side view of sclereid cells showing radially elongated cells, heavily thickened walls with slit-shaped pits and narrow lumina.
3- Top view of sclereide cells showing polygonal cells, with sharp angle and narrow lumina, while basal view of sclereid cells showing polygonal cells with sharp angles and wide lumina.

4- Numerous non-glandular trichomes which are unicellular and covered with smooth cuticle.

5- Fragments of lignified fibers have moderately thick walls and slightly wide lumina. 

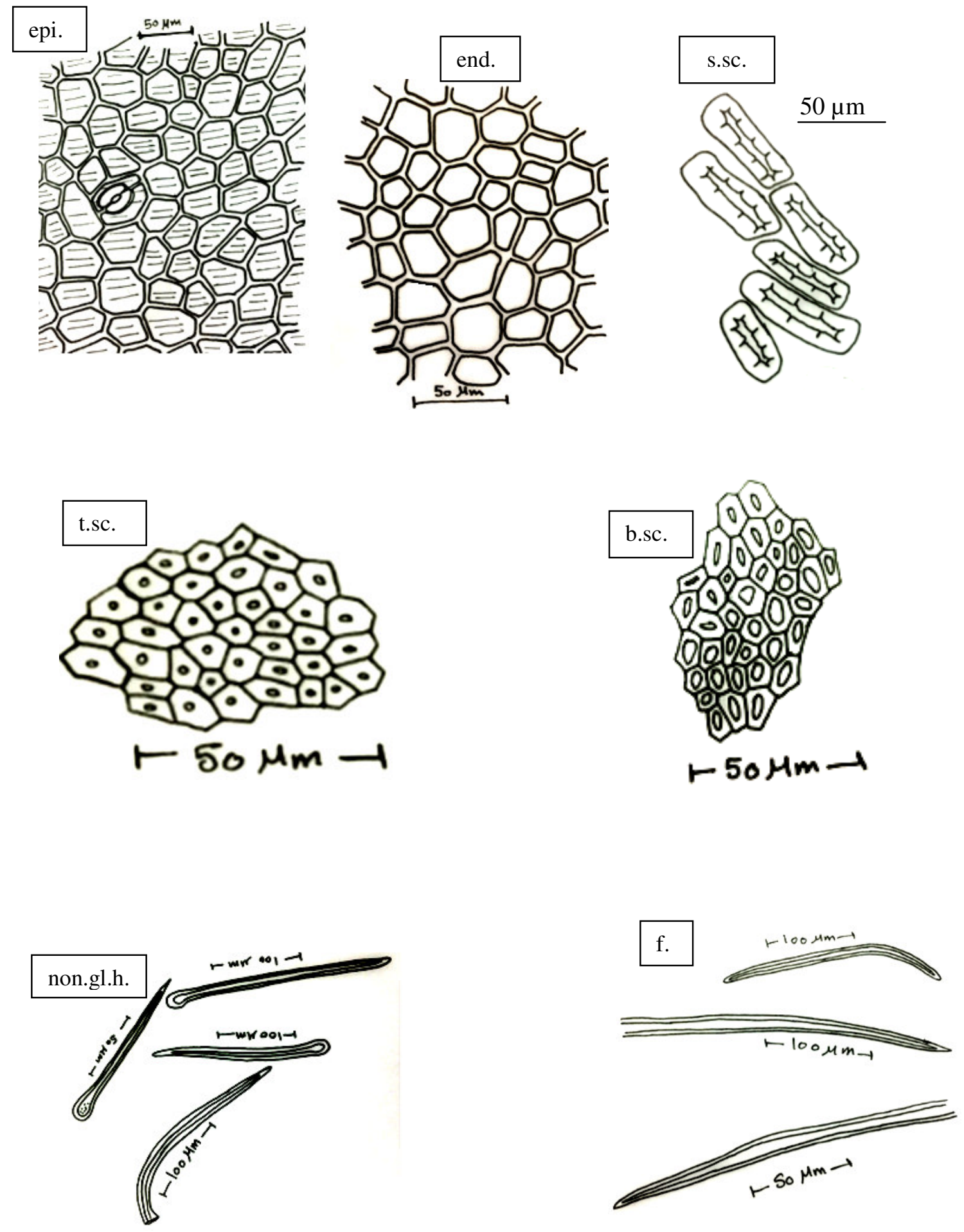

Fig. 16: Powder of the fruit.

b.sc., basal view of sclereids;end., endocarp; epi., epicarp;f., fibers; non.gl.h., non glandular hairs; s.sc., side view of sclereids; t.sc., top view of sclereids 
Table 4: Microscopical measurements of the fruit of Ipomoea eriocarpa R.Br. (In microns).

\begin{tabular}{||l|c|c|c|c||}
\hline \multicolumn{1}{|c|}{ Item } & Length & Width & Height & Diameter \\
\hline Epicarp & $44.4-\underline{50}-55.5$ & $5.6-\underline{22.2-33.3}$ & $20.5-\underline{25}-27.3$ & $6.8-\underline{18.2}-25$ \\
\hline Parenchyma & & & & $20.5-\underline{25}-31.8$ \\
\hline Sclerides & $50-\underline{60.7-75}$ & $14.3-\underline{17.9-21.4}$ & $36.4-\underline{45.5}-50$ & $6.8-\underline{11.4-13.6}$ \\
\hline Resin Cavity & & & & $77.3-79.5-81.8$ \\
\hline Fiber & $300-\underline{347-400}$ & & & $5.5-\underline{11.11}-16.7$ \\
\hline Endocarp & $14.3-\underline{26.2-30.9}$ & $7.1-9.5-11.9$ & $4.5-\underline{6.8}-9.1$ & $11.4-\underline{13.6}-15.9$ \\
\hline Non glandular hair & $193.3-\underline{206.7-213}$ & $6.7-\underline{13.3}-20$ & & \\
\hline
\end{tabular}

\section{REFERENCES}

1- C. Okereke, F. Iroka and M. Chukwuma, "Assessing the morphological and taxonomic characteristics of some members of convolvulaceae family", Int.

J. Herb. Med., 2 (5 Part A), 38-42 (2014).

2- D. F. Austin, et al., "Convolvulaceae (Morning glory family)", J. Arizona Acad. Sci., 30 (2), 61-83 (1998).

3- S. Stefanović, L. Krueger and R. G. Olmstead, "Monophyly of the Convolvulaceae and circumscription of their major lineages based on DNA sequences of multiple chloroplast loci", Am. J. Bot., 89 (9), 1510-1522 (2002).

4- S. Rabei, et al., "Conventional keys for convolvulaceae in the flora of Egypt", $\boldsymbol{F l}$. Medit., 22, 45-62 (2012).

5- R. Metcalfe and Chalk, "Anatomy of the Dicotyledons", The Clarendon Press, Oxford, Vol. 2, 1950, pp. 657-660.

6- M. Meira, E. P. d. Silva, J. M. David and J. P. David, "Review of the genus Ipomoea: traditional uses, chemistry and biological activities", Rev. Bra. de Farmacogn., 22 (3), 682-713 (2012).

7- S. Cao, R. C. Guza, J. H. Wisse, J. S. Miller, R. Evans and D. G. Kingston, "Ipomoeassins AE, cytotoxic macrocyclic glycoresins from the leaves of Ipomoea squamosa from the Suriname Rainforest 1", J. Nat. Prod., 68 (4), 487-492 (2005).
8- H. Burkill, "The Useful Plants of West Tropical Africa", Vol 1, Families AD Royal Botanic Gardens, Kew, Library MARC record. (1985).

9- G. Grubben and O. Denton, "Plant Resources of Tropical Africa 2. Vegetables. PROTA Foundation", Wageningen, Netherlands, Backhuys Publishers, Leiden, Netherlands/CTA, Wageningen, Netherlands (2004).

10- M. Das, G. Babu, R. Vidya and M. Himaja. "GC-MS analysis, antimicrobial and insecticidal activity of the leaves of Ipomoea eriocatpa", J. Indian Chem. Soc., 92 (4), 542-544 (2015).

11- K. Thamizhvanan, P. Kumuda and B. Sateesh, "Evaluation of antioxidant activity of whole plant of Ipomoea eriocarpa extract", IJIDD, 2, 1-3 (2012).

12- M. Das and M. Himaja, "Phytochemical screening, GC-MS analysis and biological activity of Ipomoea eriocarpa leaf extracts", Int. J. Pharm. Pharm. Sci., 6, 592-594 (2014). 


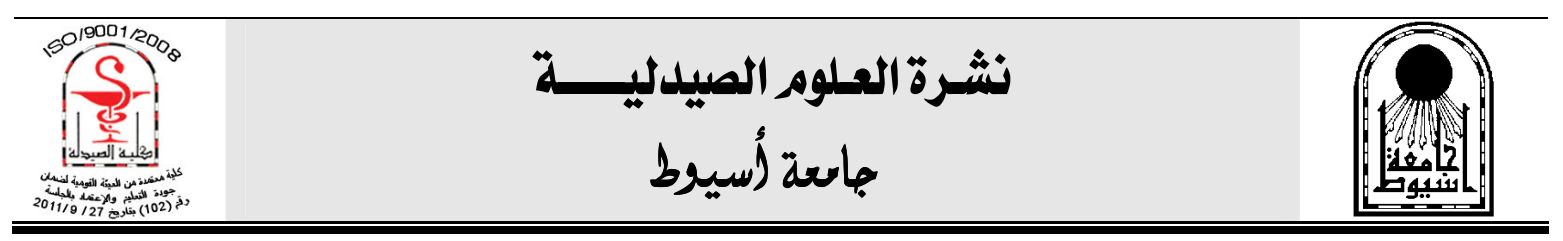

\section{دراسة عيانية ومجهرية لأوراق وسيقان وبذور وثمار نبات الإيبوميا ايريوكاربا

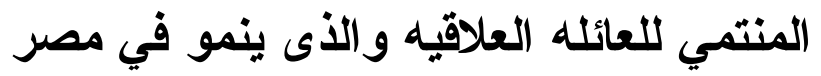

عزه عباس خليفه - أحمد عابدين محمد - زيدان زيد ابرهيم - الثيماء محمد علي

\section{قسم العقاقير، كليه الصيدله ، جامعه اسيوط ، مصر}

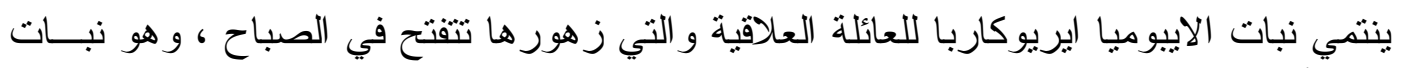

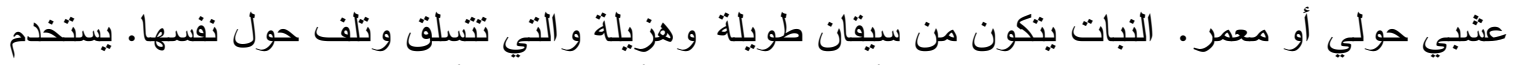

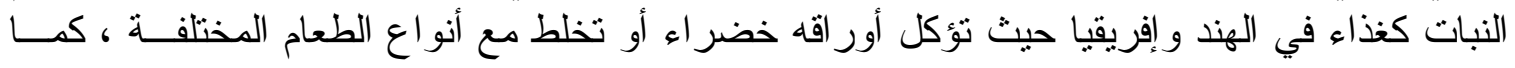

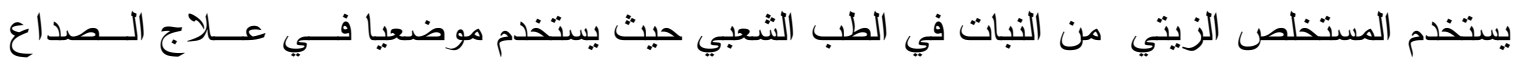

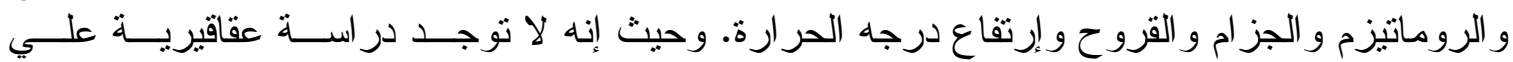

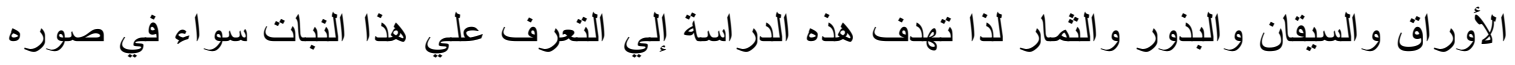
كاملة أو علي هيئه مسحوق. 